\title{
Potato Early Dying and Yield Responses to Compost, Green Manures, Seed Meal and Chemical Treatments
}

\author{
Oscar I. Molina • Mario Tenuta • Abdelbasset El Hadrami • \\ Katherine Buckley • Curtis Cavers · Fouad Daayf
}

Published online: 25 February 2014

(C) The Author(s) 2014. This article is published with open access at Springerlink.com

\begin{abstract}
Verticillium dahliae Kleb. is a soilborne fungal pathogen of many crops. In potato, it is the major causal agent of Early Dying. In Manitoba, potato fields planted with cv. Russet Burbank are infested with highly pathogenic $V$. dahliae isolates, which can produce up to $90 \%$ disease severity. The objective of the study was to evaluate selected compost, green manure, and seed-meal treatments, in comparison with the soil fumigant Vapam, for their ability to reduce propagule density of $V$. dahliae in soil and decrease disease, and to enhance potato yield. Select green manure crops (oriental and white mustard, Canada milk vetch, sorghum-sudangrass, rye, alfalfa, oat/pea mixture), organic amendments (composted cattle manure and mustard seed-meal), and Vapam, and crop sequences that contribute to the suppression of Verticillium, or the improvement of
\end{abstract}

\section{O. I. Molina}

Department of Soil Science, University of Manitoba, 13 Freedman Crescent. Ellis Building, Winnipeg, Manitoba R3T 2N2, Canada

M. Tenuta $(\bowtie)$

Canada Research Chair in Applied Soil Ecology, Department of Soil

Science, University of Manitoba, 13 Freedman Crescent. Ellis

Building, Winnipeg, Manitoba R3T 2N2, Canada

e-mail: mario.tenuta@umanitoba.ca

\section{A. El Hadrami}

Omex Agriculture Inc, 2090 Agri Park Rd., Oak Bluff,

Manitoba R4G 0A5, Canada

K. Buckley

Agriculture and Agri-Food Canada, Brandon Research Centre, 2701

Grand Valley, Brandon, Manitoba R7A 5Y3, Canada

C. Cavers

Canada Manitoba Crop Diversification Centre, Box 309, Carberry,

Manitoba R0K 0H0, Canada

F. Daayf

Department of Plant Science, University of Manitoba, 222

Agriculture Building, Winnipeg, Manitoba R3T 2N2, Canada potato yield were used in a 3-year field study initiated in 2006. Survival in soil of microsclerotia was evaluated as a measure of treatments' success in potentially reducing Early Dying. Compost and seed-meal treatments, compared to an untreated control, reduced incidence to 30 and $40 \%$, respectively, but only seed-meal reduced $V$. dahliae propagule density. Overall, green manures over 1 or 2-years were ineffective in reducing propagule density or improving potato yield. Vapam was partially effective in reducing the propagule density only at the beginning of the potato season, but it did not reduce disease incidence compared to the control. Compost and seed-meal are promising as alternative control of $V$. dahliae. Only compost reduced disease and increased potato yield, which was associated with improved nutrient availability (phosphorus and sulfate) in soil.

Resumen Verticillium dahliae Kleb., es un hongo patógeno del suelo para muchos cultivos. En papa, es el principal agente causal de muerte temprana. En Manitoba, los campos de papa con la variedad Russet Burbank están infestados con aislamientos altamente patogénicos de $V$. dahliae, que pueden producir hasta $90 \%$ de severidad de la enfermedad. El objetivo del estudio fue evaluar composta selecta, abono verde, y harina de semillas, en comparación con el fumigante del suelo Vapam, respecto a su habilidad para reducir la densidad de propágulo de $V$. dahliae en el suelo y la enfermedad posterior, y en el aumento en el rendimiento de papa. En un estudio de campo de tres años iniciado en 2006, se usaron cultivos selectos de abono verde (mostaza oriental y blanca, milkvetch canadiense (Astragalus Canadensis, Leguminosae), sorgo-pasto sudan, Centeno, alfalfa, mezcla avena-chícharo), mejoradores orgánicos (estiércol vacuno composteado y harina de semilla de mostaza), y Vapam, con seguimiento al cultivo, en la contribución a la supresión de Verticillium, o en el mejoramiento del rendimiento de papa. Se evaluó la sobrevivencia en suelo de los microesclerocios como una medida de éxito de los tratamientos en la 
reducción potencial de la muerte temprana. Los tratamientos con composta y de harina de semillas, comparados con un testigo sin tratar, redujeron la incidencia a 30 y $40 \%$ respectivamente, pero únicamente la harina de semillas redujo la densidad de propágulo de $V$. dahliae. En general, los abonos verdes en uno o dos años, no fueron efectivos en la reducción de la densidad de propágulo o en el mejoramiento en el rendimiento de papa. Vapam fue parcialmente efectivo en la reducción de la densidad de propágulo únicamente al principio del ciclo de cultivo, pero no redujo la incidencia de la enfermedad en comparación con el testigo. La composta y la harina de semillas son prometedoras como control alternativo de $V$. dahliae. Solo la composta redujo la enfermedad y aumentó el rendimiento de papa, que estuvo asociado con el mejoramiento de la disponibilidad de nutrientes (fósforo y sulfato) en el suelo.

Keywords Potato Early Dying - Verticillium dahliae · Potato · Green manure · Compost · Seed meal · Microsclerotia . Control

\section{Introduction}

Potato Early Dying (PED) is responsible for $30 \%$ to $50 \%$ potato yield reduction in severely affected fields of North America (Davis et al. 2001; Powelson and Rowe 1993). Verticillium dahliae Kleb., the main causal agent of PED, is a soilborne fungal pathogen of potato found in many growing regions around the world. Control of PED is extremely difficult due to the formation of microsclerotial resting structures by $V$. dahliae, which can survive in soil for up to 10-20 years (Huisman and Ashworth 1976; Schnathorst 1981). Management of PED depends on a variety of strategies to prevent the germination and/or reduce microsclerotia density in soil. Soil fumigation with metam sodium (Vapam) alone or in combination with other fumigants has been an effective method of controlling PED (Rowe and Powelson 2002; Tsror et al. 2005). However, concern over potential negative effects on human health and/or environmental damage as well as high cost have urged the search for alternative strategies to manage PED (Davis et al. 1996).

Green manuring is a cultural practice that uses plant material incorporated into soil while green or at maturity (Fageria 2007). Green manures as well as organic amendments such as animal manures and composts are frequently used for improving soil quality. They also provide nutrients to crops and may be suppressive to some soilborne pathogens such as $V$. dahliae (Davis et al. 2010a; Davis et al. 1996; Lambert et al. 2005; Ochiai et al. 2008). Incidence of PED has been reduced using pea (Pisum sativum), oat (Avena sativa), sudan-grass (Sorghum vulgare) and corn (Zea mays) green manures (Davis et al. 2010b, 1999; Ochiai et al. 2008; Wiggins and
Kinkel 2005b), animal manures (Conn and Lazarovits 1999; Tenuta et al. 2002) and compost (LaMondia et al. 1999).

Even though reduction of PED using green manure or organic amendments is often inconsistent and unpredictable, a variety of mechanisms responsible for killing $V$. dahliae microsclerotia have been determined. Tenuta and Lazarovits (2002a) demonstrated that ammonia $\left(\mathrm{NH}_{3}\right)$ and nitrous acid $\left(\mathrm{HNO}_{2}\right)$ from meat and bone meal killed microsclerotia in soil. Olivier et al. (1999) suggested that incorporation of glucosinolate (GLS) containing plants, such as members of the Brassicaceae, reduce $V$. dahliae propagules due to the toxicity of hydrolysis products such as isothiocyanates (ITCs). Organic amendments such as compost stimulate the activity of microbial communities, such as copiotrophic and oligothrophic bacteria, against $V$. dahliae (Termorshuizen et al. 2006).

However, incorporation of green manures have also resulted in no reduction or even increased $V$. dahliae microsclerotia density in soil (Collins et al. 2005). Studies with Sudan-grass and corn green manures suggest that reduction of disease incidence is not always associated with lowering propagule density of V. dahliae (Davis et al. 1999; Davis et al. 1996); it can also be attributed to improved soil fertility (Lambert et al. 2005; Rowe and Powelson 2002) and increased microbial respiration, and increased microbial biomass $\mathrm{C}$ and FDA hydrolysis (Ochiai et al. 2008). Canada milk vetch green manure might reduce severity of PED due to the production of fungitoxic compounds or an induction of defense response in potato against $V$. dahliae (Uppal et al. 2008). Oat/peas, fall rye, sorghum-sudangrass and alfalfa green manures and composted beef-cattle manure may also suppress PED by changing soil conditions $(\mathrm{N}$, soil $\mathrm{pH}, \mathrm{Ca}, \mathrm{K}$, total $\mathrm{C}$ and microbial biomass) (Ochiai et al. 2008).

In Manitoba, potato fields planted with the processing potato 'Russet Burbank' are infested with highly pathogenic $V$. dahliae isolates, which can infect up to $90 \%$ of the plant tissue (Uppal et al. 2007) and ultimately reduce potato yield. The effectiveness of green manures and organic amendments for reducing $V$. dahliae microsclerotia and PED has not been examined in Manitoba. Therefore, the objective of this study was to evaluate selected green manure and organic amendments for their ability to reduce $V$. dahliae microsclerotia density in soil, PED development, and to enhance soil fertility and potato yield under Manitoba growing conditions. A chemical treatment of metam sodium was used as a standard control.

\section{Materials and Methods}

\section{Crop Sequences and Design}

An experiment was conducted at the Canada-Manitoba Crop Diversification Centre (CMCDC) near Carberry, Manitoba, 
between 2006 and 2008. The soil was a Ramada loam $\left(\mathrm{pH}_{\text {water }}\right.$ 6.0 , EC $0.46 \mathrm{dSm}^{-1}$ and organic matter $51 \mathrm{~g} \mathrm{~kg}^{-1}$ ) naturally infested with $V$. dahliae (7 colony forming units (CFU) $\mathrm{g}^{-1}$ soil) (0-15 cm depth; spring, 2006). The field was planted to potato in the season preceding the start of this study in 2005 . The experimental design was a randomized complete block with four blocks and 12 treatments. A total of 48 individual plots, $18 \mathrm{~m}$ long x $6 \mathrm{~m}$ wide, were separated by $2 \mathrm{~m}$ between plots and $10 \mathrm{~m}$ between each block with fallow soil.

In 2006, plots of ten treatments were planted (23 May 2006) to spring wheat (Triticum aestivum L., 'AC Cora') $\left(123 \mathrm{~kg} \mathrm{ha}^{-1}\right)$. Plots of two treatments were planted (25 May 2006) to sorghum-sudangrass hybrid (Sorghum bicolor L. Moench, 'Super Su 22') (29 $\left.\mathrm{kg} \mathrm{ha}^{-1}\right)$ (treatment SS2), and alfalfa (Medicago sativa $\mathrm{L}$.) $\left(9 \mathrm{~kg} \mathrm{ha}^{-1}\right)$ (treatment ALF), respectively. The spring wheat plots were harvested, plant biomass of the SS2 plots were disc-incorporated to a depth of $15 \mathrm{~cm}$, and ALF plots cut down and mechanically harvested for animal feed on 19 September 2006 (Table 1).

In 2007, alfalfa regrew in the same plots it was planted in 2006, and the SS2 treatment was re-planted with sorghumsudangrass on the same plots. Plots of one treatment were planted to spring wheat and used as the crop control treatment (control). Plots of six green manure treatments were planted on 29 May 2007 to white mustard (Sinapis alba L. 'Ace') $\left(9 \mathrm{~kg} \mathrm{ha}^{-1}\right)$ (treatment MUSTwh); oriental mustard (Brassica juncea L. 'Cutlas') (5 $\left.\mathrm{kg} \mathrm{ha}^{-1}\right)$ (treatment MUSTor); oat (Avena sativa L 'Triple Crown')/pea (Pisum sativum L. '40-10 Forage
Pea' (86 kg ha ${ }^{-1}$ ) (treatment O/PEA); Canada milk vetch (Astragalus canadensis L.) $\left(11 \mathrm{~kg} \mathrm{ha}^{-1}\right)$ (treatment CMV); fall rye (Secale cereale L.) $\left(81 \mathrm{~kg} \mathrm{ha}^{-1}\right)$ (treatment RYE) and sorghum-sudan-grass (treatment SS1). Composted beef cattle manure (COM) produced at AAFC Brandon, $\mathrm{MB}$ ), was hand applied to one set of the treatment plots (four plots), before wheat planting, at a rate of 44.5 wet $\mathrm{Mg} \mathrm{ha}^{-1}$ (45\% moisture, $1.28 \% \mathrm{~N}, 0.5 \% \mathrm{P})$. The remaining set of treatment plots (16 plots) were planted to spring wheat on 30 May 2007. Treatment plots with green manure crops were cut down and mechanically incorporated in soil to a depth of 15-20 cm, between August and September 2007, by either disc or rototiller. The fresh matter $\left(\mathrm{Mg} \mathrm{ha}^{-1}\right)$ of green manures incorporated in 2007 was 34.5 MUSTor, 33.3 MUSTwh, 34.8 O/PEA, 53.8 SS2, 48.8 SS1, 6.5 RYE, 8.3 CMV, and 21.0 ALF. Plots planted to spring wheat were harvested on 15 October 2007. Soil fumigation with Vapam (32.7\% sodium methyldithiocarbamate, United Agriproducts, MB) (VAP) was conducted on 15 October 2007, immediately after harvest of one set of plots with spring-wheat. Before fumigation, plots were cultivated with a tandem disk followed by roto-tilling to loosen the soil to a depth of $15 \mathrm{~cm}$. The fumigant was mixed with water and injected into plot areas, at 5,000 $\mathrm{L} \mathrm{ha}^{-1}(762 \mathrm{~L}$ Vapam $\mathrm{ha}^{-1}$ ) which is what was recommended by the product distributor at the time of the study. The more concentrated product formulation (Vapam HL, $42 \%$ sodium methyldithiocarbamate) was not commercially available in Canada at the time of this study.

Table 1 Crops, green manures, organic amendments and Vapam treatments used in the study

\begin{tabular}{|c|c|c|c|c|c|c|}
\hline \multirow[t]{2}{*}{ Treatment $^{\mathrm{a}}$} & \multicolumn{2}{|l|}{2006} & \multicolumn{2}{|l|}{2007} & \multicolumn{2}{|l|}{2008} \\
\hline & Crop & Amendment & Crop & Amendment & Crop & Amendment \\
\hline Control & Spring Wheat & $N / A^{b}$ & Spring Wheat & N/A & Potato & N/A \\
\hline $\mathrm{COM}$ & Spring Wheat & N/A & Spring Wheat & May/Compost & Potato & May/Compost \\
\hline MUSTmeal & Spring Wheat & N/A & Spring Wheat & N/A & Potato & May/Seed-Meal \\
\hline VAP & Spring Wheat & N/A & Spring Wheat & Oct./Vapam & Potato & N/A \\
\hline $\mathrm{O} / \mathrm{PEA}$ & Spring Wheat & N/A & Oat/Peas & August/GM & Potato & N/A \\
\hline CMV & Spring Wheat & N/A & Can. Milk Vetch & August/GM & Potato & N/A \\
\hline RYE & Spring Wheat & N/A & Fall rye & August/GM & Potato & N/A \\
\hline MUSTor & Spring Wheat & N/A & Brown mustard & August/GM & Potato & N/A \\
\hline MUSTwh & Spring Wheat & N/A & White Mustard & August/GM & Potato & N/A \\
\hline SS1 & Spring Wheat & N/A & Sorghum-Sudan & August/GM & Potato & N/A \\
\hline SS2 & Sorghum-Sudan & Sept./GM ${ }^{\mathrm{c}}$ & Sorghum-Sudan & August/GM & Potato & N/A \\
\hline ALF & Alfalfa & Sept./CDH ${ }^{\mathrm{d}}$ & Alfalfa & August/GM & Potato & N/A \\
\hline
\end{tabular}

${ }^{\mathrm{a}}$ Treatments: Control=wheat-control, $\mathrm{COM}=$ compost, $\mathrm{MUST}_{\text {meal }}=$ mustard seed-meal, $\mathrm{VAP}=\mathrm{Vapam}, \mathrm{O} / \mathrm{PEA}=\mathrm{oat} /$ peas mix, $\mathrm{CMV}=\mathrm{Canada}$ milk vetch, $\mathrm{SS} 2=2$-years sorghum-sudangrass, SS1=1-year sorghum-sudangrass, RYE=fall rye, MUSTor=Oriental mustard, MUSTwh=white mustard, and $\mathrm{ALF}=$ alfalfa

${ }^{\mathrm{b}} N / A$ Non-amendment at that particular time

${ }^{\mathrm{c}} G M$ Green manure

${ }^{\mathrm{d}} \mathrm{CDH}$ Cut down and mechanically harvested for animal feed 
In 2008 , to one set of plots previously planted to springwheat, mustard seed meal (treatment MUSTmeal) was added as an organic amendment treatment prior planting of potato. The seed meal was in the form of partially de-oiled oriental mustard seed containing a high level of GLS sinigrin $(0.85 \%)$, $25 \%$ protein, $8 \%$ moisture and $4-6 \%$ ash content (Mustard Capital Inc., Gravelbourg, SK). Mustard seed meal was broadcasted by hand to the soil surface at a concentration of $0.5 \%$ ( $\mathrm{w} \mathrm{w}^{-1}$ ) (field equivalent $9,000 \mathrm{Mg} \mathrm{ha}^{-1}$ ) and incorporated into soil with a rototiller on 15 May. On 16 May, compost was incorporated at a rate of 44.5 wet $\mathrm{Mg} \mathrm{ha}^{-1}$ to the same treatment plots it was applied in the previous year (Table 1).

On 21 May 2008, all plots were planted to potato (Solanum tuberosum 'Russet Burbank'). Seed rows were $1 \mathrm{~m}$ apart, with six rows per plot, and within row spacing of $0.25 \mathrm{~m}$. Prior to planting, each plot received a broadcast application of nutrients based on soil fertility analysis $\left(\mathrm{NO}_{3}{ }^{-}\right.$, Olsen-P, ammonium acetate-K) and recommendation guidelines in Manitoba (Province of Manitoba Soil Fertility Guide). Treatments were grouped according to soil fertility test levels as follows: Group 1-control, VAP, COM, MUSTmeal, RYE, SS2 and ALF treatments received $34 \mathrm{~kg} \mathrm{~N} \mathrm{ha}^{-1}, 45 \mathrm{~kg} \mathrm{P}_{2} \mathrm{O}_{5} \mathrm{ha}^{-1}$ and $78 \mathrm{~kg} \mathrm{~K}_{2} \mathrm{O}$ $\mathrm{ha}^{-1}$; Group 2-O/PEA, MUSTwh, MUSTor and SS1 treatments received $90 \mathrm{~kg} \mathrm{~N} \mathrm{ha}^{-1}, 45 \mathrm{~kg} \mathrm{P}_{2} \mathrm{O}_{5} \mathrm{ha}^{-1}$ and $78 \mathrm{~kg}$ $\mathrm{K}_{2} \mathrm{O}$ ha $^{-1}$. Nitrogen, $\mathrm{P}$ and $\mathrm{K}$ were added as commercial urea, monoammonium phosphate and potassium chloride fertilizers, respectively. Soil was disked to $15 \mathrm{~cm}$ following fertilizer application. Potato hilling was done on 24 June 2008 with no additional fertilizer application.

\section{Survival of Buried Verticillium dahliae Microsclerotia}

An in-situ soil bioassay was used to determine the fungitoxic effect of MUSTmeal, VAP, O/PEA, CMV, SS2, SS1, RYE, MUSTor, MUSTwt and ALF treatments on the survival of $V$. dahliae microsclerotia. Microsclerotia from a highly pathogenic isolate of $V$. dahliae (vd-1396) to potato (Uppal et al. 2007) were produced in the laboratory on semisolid CzapekDox medium for 3-4 weeks in the dark at $24{ }^{\circ} \mathrm{C}$ (Hawke and Lazarovits 1994). The culture was poured through mesh screens to obtain microsclerotia 75 to $106 \mu \mathrm{m}$ in diameter. Survival response to the treatments was determined using a microsclerotia in silica sand mixture added to nylon mesh bags (SAATILON ${ }^{\circledR}$ monofilament) (Tenuta and Lazarovits 2002b). The mesh bags were buried in soil to a $10 \mathrm{~cm}$ depth immediately following treatment incorporation of green manure, seed meal and Vapam treatments, and retrieved 1 and 3 weeks later. Bags were then dried at room temperature for $12 \mathrm{~h}$ and their contents spread onto a pectate-tergitol-agar plate using an Andersen Cascade Impactor (Andersen Instruments Inc., Smyrna, GA). The agar plates were then incubated for 57 days in the dark at $24{ }^{\circ} \mathrm{C}$ and the germination of microsclerotia determined as the percentage of number of microsclerotia examined that germinated to form colonies.

\section{Verticillium dahliae Propagule Density in Soil}

A composite soil sample consisting of 20 soil cores was taken randomly from the hills of each treatment plot with a $2.5 \mathrm{~cm}$ diameter soil probe to a depth of $15 \mathrm{~cm}$, at four times: before green manure and spring-wheat crops were planted (May 2007), immediately after spring wheat was harvested and approximately 2 months after incorporation of green manures (September 2007), prior to planting potato (April 2008) and immediately after potato harvest (August 2008). Soil cores from each plot were bulked, placed in polyethylene bags, and transported in an ice chest to the University of Manitoba. The samples were mixed by hand and stored at $4{ }^{\circ} \mathrm{C}$. Samples were stored for no more than 2 weeks before starting determination of $V$. dahliae propagule density in soil.

A $100 \mathrm{~g}$ subsample of each soil sample was air-dried for 7 days at room temperature and then $5 \mathrm{~g}$ were suspended in $100 \mathrm{~mL}$ of sterilized agar-water (1\%), and agitated for $2 \mathrm{~min}$ using an orbital shaker at $60 \mathrm{rpm}$. One milliliter of the suspension was placed onto plates of Sorensen's NP-10 medium (Sorensen et al. 1991) containing chloramphenicol, streptomycin sulphate and chlortetracycline $\mathrm{HCl}$. Each sample was plated ten times. Plates were incubated for 15 days in the dark at $22{ }^{\circ} \mathrm{C}$. They were then rinsed with tap water to remove soil particles from the medium surface. The number of germinated $V$. dahliae microsclerotia was counted using a stereomicroscope, and expressed as V. dahliae $\mathrm{CFU} \mathrm{\textrm {g } ^ { - 1 }}$ soil.

\section{Disease Incidence and Severity}

PED incidence was determined late in the growing season (25 August 2008) as the proportion of plants examined with symptoms in each plot. The symptoms observed were uneven chlorosis of the lower leaves or flagging unilateral leaf wilting or death (Rowe et al. 1987). For disease severity determination, ten plants were dug from one row on each side of a plot. Disease severity by $V$. dahliae was assessed by taking a stem portion from the upper, middle and lower section of the plant. Stem portions were then vertically split to estimate the percentage of vascular tissue discolored from each section using a predetermined scale of 0 to 5 , in which $0=0 \%, 1=1-10 \%$, $2=11-30 \%, 3=31-50 \%, 4=51-75 \%$, and $5=76-100 \%$ discoloration (Uppal et al. 2008).

\section{Soil Chemical Analysis}

For soil chemical analysis, three cores per plot were taken (from the hills and between plants, if present) on 14 May (before planting), 8 July (middle of the season) and 22 August (after harvest) at two depths: $0-15 \mathrm{~cm}$ for sodium 
bicarbonate extractable-P, ammonium acetate extractable-K, $\mathrm{pH}$ and electrical conductivity (by 1:2 soil:water ratio method), and $15-60 \mathrm{~cm}$ for the mobile nutrients, nitrate and sulfate. The three soil cores from each plot were bulked, placed in polyethylene bags, and transported on ice to the University of Manitoba, where each bag was mixed by hand and stored at $4{ }^{\circ} \mathrm{C}$. Samples were stored for no more than $24 \mathrm{~h}$ before sending to Bodycote Laboratory (Winnipeg, MB.) for analysis.

\section{Potato Yield and Quality}

Crop yield was determined by harvesting the two central rows of each plot on 22 August 2008. Experimental plots were mechanically harvested. Potato tubers were placed in open fiber bags, transported to the CMCDC station and stored at $5^{\circ} \mathrm{C}$ until sample processing. Samples were then washed and weighed to determine weight loss and washed. Based on tuber weight analysis, the size categories for marketable yield were: non-marketable tubers $<85 \mathrm{~g}$, regular $86-170 \mathrm{~g}$, bonus $170.1-$ $340 \mathrm{~g}$ and overweight $>340 \mathrm{~g}$. Yield was expressed as $\mathrm{Mg} \mathrm{ha}^{-1}$. Specific gravity was determined using the weight in air and water method, fry color analysis by using USDA Fry Color Chart, green color, rot and hollow heart by tuber observation, and sugar end analyses by frying and comparing color with a standard chart.

\section{Statistical Analysis}

All statistical analyses were performed with the Statistical Analysis Software (SAS Institute, Cary, NC; release 9.1). Prior to analysis, $V$. dahliae propagule density in soil, disease incidence and severity, and marketable yield data sets were checked for normality (PROC Univariate). Survival rate of buried $V$. dahliae microsclerotia was arcsine transformed before analysis, and it is presented as percentage of the control (microsclerotia germination of control $=100 \%$ ). The data were analyzed by analysis of variance using the PROC MIXED procedure in SAS. Block was considered a random variable. Treatment means were separated using the Bonferronni's procedure if the F-test was significant $(P<0.05)$. Contrasts were used to test the significance of differences between groups of treatments. Linear and nonlinear regression analyses were used to examine the relationships of inoculum density and selected soil characteristics on PED disease incidence and potato tuber yield. MUSTmeal was excluded from the regression analyses of measures to tuber yields because plants remained in vegetative growth while other treatments senesced at harvest. $V$. dahliae propagule density in soil, disease incidence and severity, chemical parameters and marketable yield and categories were then subjected to stepwise regression analysis to determine if the relationship between two or more independent variable(s) during the 2-year study can be used to construct a model that predict disease incidence and potato tuber yield. Differences were considered significant at $P<0.05$.

\section{Results}

Survival of Buried Verticillium dahliae Microsclerotia

The bioassay results showed that germination of buried $V$. dahliae microsclerotia was affected by treatment $(P<0.0001)$ and time after treatment application $(P<0.006)$. In general, the germination percentage of buried microsclerotia relative to the control was lower at 3 weeks than 1 week post treatment, except for MUSTmeal treatment which increased slightly after 3 weeks (Fig. 1). VAP and MUSTmeal were the most effective treatments reducing germination of microsclerotia $(P<0.0001)$. One week following incorporation, MUSTwh, MUSTor and O/PEA reduced germination of microsclerotia by about $40 \%$ compared to the control. In contrast, CMV, SS1, SS2, RYE and ALF treatments did not affect the germination of $V$. dahliae microsclerotia (Fig. 1). Three weeks after application, VAP was the most effective treatment reducing germination to $5 \%$ of the control $(P<0.0001)$. In contrast, MUSTmeal treatment was less effective after 3 weeks with the germination of microsclerotia being $24 \%$ of the control (Fig. 1). Germination of $V$. dahliae microsclerotia decreased slightly with green manure treatments ranging from 60 to $90 \%$ of the control. However, germination of microsclerotia in O/PEA, SS2, MUSTor and MUSTwh treatments was not significantly different from the MUSTmeal treatment. Although the germination of microsclerotia observed in SS1, ALF, RYE and CMV treatments was not significantly different from other green manure treatments, it was significantly higher than MUSTmeal $(P<0.05)$.

\section{Verticillium dahliae Propagule Density in Soil}

Mean soil densities of $V$. dahliae in spring and fall 2007 were 6 and $8 \mathrm{CFU} \mathrm{g}^{-1}$ soil, respectively. Propagule density was not affected by incorporation of the green manures in 2007 . However, contrast analysis showed lower density in MUSTwh and MUSTor compared to other green manure treatments $(P=0.0296$, Table 2$)$.

Propagule density in soil also differed among treatments in the spring and fall of the potato year of the experiment (2008) ( $P=0.0001$ ). In spring 2008, MUSTwh was the only green manure treatment with a lower density of propagules than the control $(P=0.0002)$. MUSTwh, MUSTor and O/PEA treatments maintained low propagule density ranging from 3 to $7 \mathrm{CFU} \mathrm{g}^{-1}$ soil. The application of Vapam the previous fall had reduced the density of propagules in soil from 9 to 


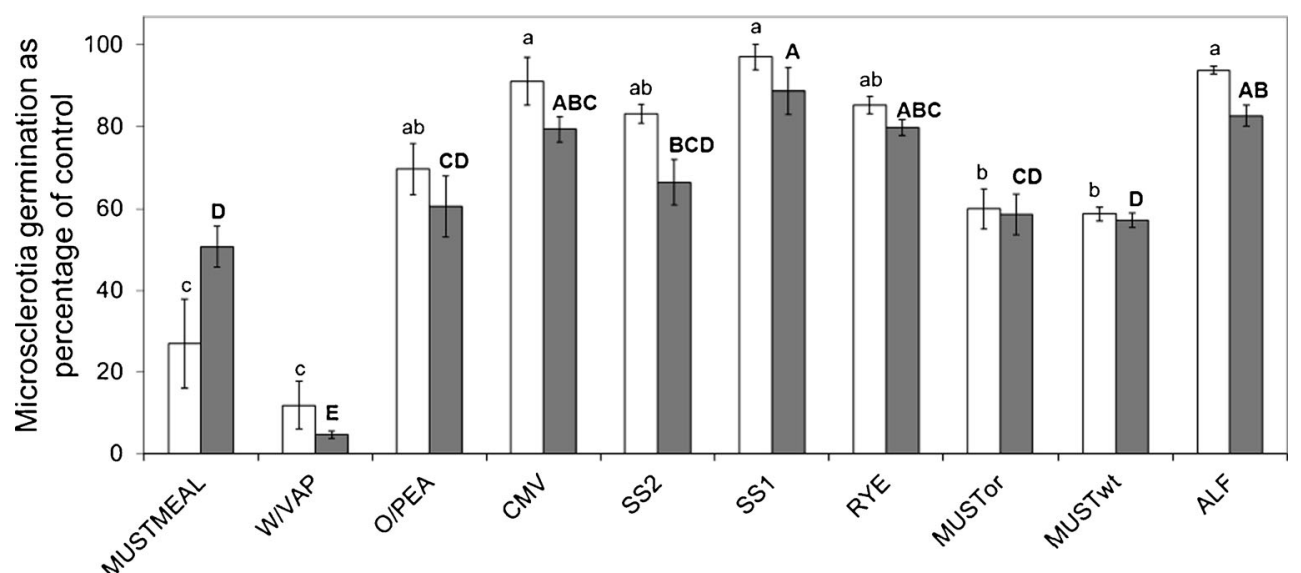

Treatments

Fig. 1 Bioassay results for the effect of mustard seed meal, Vapam and green manures on germination of buried $V$. dahliae microsclerotia, expressed as a percentage of germination of microsclerotia relative to the control at 1 week (empty square) and 3 weeks (filled square) after application. $\mathrm{MUST}_{\text {meal }}=$ mustard seed meal, VAP=Vapam, O/PEA=oat/ pea mix, CMV=Canada milk vetch, SS2=2-years sorghum-sudangrass,
SS1=1-year sorghum-sudangrass, RYE=fall rye, MUSTor=oriental mustard, MUSTwh=white mustard, and ALF=alfalfa. Means within a sampling time followed by the same letter are not statistical different according to the Bonferroni's multiple comparison test $(P>0.05)$. Error bars are +1 standard error

ranged from 11 to $45 \%, 1$ to $25 \%$, and less than $1 \%$ for lower, middle and upper potato stem sections, respectively (data not shown).

\section{Plant and Soil Assessment}

In general, organic amendments and green manures promoted significant changes in soil fertility levels and potato yield. MUSTmeal treatment increased $\mathrm{NO}_{3}{ }^{-} \mathrm{N}\left(203 \mathrm{~kg} \mathrm{~N}^{-1}\right)$ in soil by approximately four-fold compared to the control (49 $\left.\mathrm{kg} \mathrm{N} \mathrm{ha}^{-1}\right)(P=0.0001$, Table 3$)$. Plant extractable-P concentration was significantly greater in COM $\left(65 \mathrm{~kg} \mathrm{ha}^{-1}\right)$ than in green manure treatments $\left(29-38 \mathrm{~kg} \mathrm{P} \mathrm{ha}^{-1}, P<0.0001\right)$ or any other treatment except for MUSTmeal. MUSTmeal treatment (45 $\mathrm{kg} \mathrm{N} \mathrm{ha}^{-1}$ ) also increased extractable-P compared to green manure treatments $(P=0.0105)$. Sulfate concentration was greatest in MUSTmeal and VAP treatments (142 and $139 \mathrm{~kg} \mathrm{ha}^{-1}$, respectively) compared to other treatments (34-65 kg S ha ${ }^{-1}, P=0.0001$, Table 3). The incorporation of green manure and organic amendments into soil had no effect on soil pH (Table 3). No significant difference in EC was observed among green manure, $\mathrm{COM}$ and the control treatments (EC ranged from 0.19 to $0.35 \mathrm{dS} \mathrm{m}^{-1}$ ). However, MUSTmeal treatment showed a significant increase $\left(0.52 \mathrm{dS} \mathrm{m}^{-1}\right)$ compared to the control treatment $(P=0.0016$, Table 3 ) and likely a result of accumulation of $\mathrm{NO}_{3}{ }^{-}$and sulfate.

The relationship between inoculum density at harvest and PED disease incidence was cubic ( $P=0.0068$, Fig. 2a). At harvest, there was a quadratic relationship between PED incidence and extractable-P ( $P=0.006$, Fig. $2 b)$. Further, multiple stepwise regression analysis revealed relations of high inoculum density (at harvest) and extractable-P on PED incidence. upper section of the potato stems, compared to the cont $(P>0.05$, data not shown). Severity as stem discoloration 
Table 2 Effect of wheat, green manures, organic amendments and Vapam treatments on soil propagule density of $V$. dahliae (CFU g ${ }^{-1}$ soil) and Potato Early Dying incidence

\begin{tabular}{|c|c|c|c|c|c|c|c|c|}
\hline \multirow[t]{3}{*}{ Treatment $^{\mathrm{a}}$} & \multicolumn{6}{|c|}{ V. dahliae (CFU g ${ }^{-1}$ soil) } & \multicolumn{2}{|c|}{ Incidence (\%) 2008 Augus } \\
\hline & \multicolumn{2}{|l|}{2007} & \multicolumn{4}{|l|}{2008} & & \\
\hline & May & Sept. & April & & August & & & \\
\hline Control & $3 \pm 1^{\mathrm{b}}$ & $5 \pm 2$ & $13 \pm 3$ & $\mathrm{a}$ & $27 \pm 2$ & $a b$ & $57 \pm 11$ & $a b c$ \\
\hline $\mathrm{COM}$ & $10 \pm 4$ & $6 \pm 1$ & $9 \pm 3$ & $a b$ & $12 \pm 3$ & $\mathrm{~cd}$ & $25 \pm 3$ & $\mathrm{bc}$ \\
\hline MUSTmeal & $10 \pm 6$ & $11 \pm 2$ & $15 \pm 2$ & a & $10 \pm 1$ & $\mathrm{~d}$ & $13 \pm 7$ & $\mathrm{c}$ \\
\hline VAP & $4 \pm 2$ & $9 \pm 5$ & $3 \pm 1$ & $\mathrm{~b}$ & $24 \pm 3$ & $a b c$ & $70 \pm 11$ & $a b$ \\
\hline $\mathrm{O} / \mathrm{PEA}$ & $11 \pm 5$ & $9 \pm 2$ & $7 \pm 2$ & $a b$ & $14 \pm 4$ & bcd & $47 \pm 10$ & $a b c$ \\
\hline CMV & $6 \pm 2$ & $12 \pm 6$ & $12 \pm 4$ & $\mathrm{ab}$ & $21 \pm 2$ & abcd & $48 \pm 2$ & $a b c$ \\
\hline $\mathrm{SS} 2$ & $4 \pm 3$ & $4 \pm 1$ & $11 \pm 2$ & $a b$ & $25 \pm 4$ & $a b c$ & $93 \pm 7$ & $\mathrm{a}$ \\
\hline SS1 & $6 \pm 3$ & $11 \pm 7$ & $14 \pm 3$ & $\mathrm{a}$ & $18 \pm 2$ & abcd & $62 \pm 7$ & $a b$ \\
\hline RYE & $4 \pm 2$ & $12 \pm 3$ & $18 \pm 4$ & a & $36 \pm 7$ & a & $70 \pm 10$ & $\mathrm{ab}$ \\
\hline MUSTor & $8 \pm 3$ & $7 \pm 4$ & $7 \pm 2$ & $a b$ & $15 \pm 3$ & bcd & $52 \pm 16$ & $a b c$ \\
\hline MUSTwh & $3 \pm 1$ & $3 \pm 2$ & $3 \pm 1$ & $\mathrm{~b}$ & $17 \pm 2$ & abcd & $52 \pm 6$ & $a b c$ \\
\hline ALF & $7 \pm 1$ & $7 \pm 3$ & $12 \pm 2$ & $a b$ & $20 \pm 1$ & abcd & $62 \pm 13$ & $\mathrm{ab}$ \\
\hline$P>F^{\mathrm{c}}$ & ND & ND & 0.0002 & & 0.0001 & & 0.0001 & \\
\hline \multicolumn{9}{|c|}{ Selected contrasts (significant probability). } \\
\hline Unamended vs Green manures & ND & ND & 0.0382 & & NS & & NS & \\
\hline Unamended vs VAP & ND & ND & $<0.0001$ & & ND & & ND & \\
\hline Vap vs Green manures & ND & ND & 0.0006 & & NS & & NS & \\
\hline COM vs Green manures & ND & ND & ND & & 0.0022 & & 0.0007 & \\
\hline MUSTmeal vs Green manure & ND & ND & ND & & 0.0004 & & $<0.0001$ & \\
\hline Mustards vs MUSTmeal & ND & ND & ND & & 0.0332 & & 0.0014 & \\
\hline Mustards vs Non-mustards & ND & 0.0296 & 0.0002 & & 0.0247 & & NS & \\
\hline
\end{tabular}

${ }^{\mathrm{a}}$ Treatments: Control=wheat-control, $\mathrm{COM}=$ compost, $\mathrm{MUST}_{\text {meal }}=$ mustard seed-meal, $\mathrm{VAP}=$ Vapam, $\mathrm{O} / \mathrm{PEA}=\mathrm{oat} /$ peas mix, $\mathrm{CMV}=\mathrm{Canada}$ milk vetch, $\mathrm{SS} 2=2$-years sorghum-sudangrass, SS1=1-year sorghum-sudangrass, RYE=fall rye, MUSTor=Oriental mustard, MUSTwh=white mustard, and $\mathrm{ALF}=$ alfalfa. $($ Unamended $)=$ treatments not established, but planted with spring-wheat; mustards=white and oriental mustard; non-mustards $=$ oat $/$ peas, Canada milk vetch, 1- and 2-years Sorghum-sudangrass, fall rye and alfalfa

${ }^{\mathrm{b}}$ Values are means \pm 1 standard error. Within columns means followed by the same letter are not statistical different $(P>0.05)$ according to the Bonferroni's multiple comparison test

${ }^{\mathrm{c}}$ Treatment significant probability. NS, not significant $(P>0.05)$. ND, not determined

This model explained $66 \%$ of the variability in disease incidence $(P=0.0076$, Table 5). There was no relation between inoculums density at planting and PED disease incidence (data not shown).

\section{Marketable Yield and Tuber Quality}

A significant treatment effect was observed for bonus, overweight and total marketable yield (Table 4), but not for tuber quality (fry colour, specific gravity and sugar ends of tubers) (data not shown). Total marketable yield of potato in plots amended with COM treatment were 26 and $42 \%$ higher than the control and MUSTmeal treatments $(P=0.0003)$, respectively. Contrast analyses revealed an increase in total marketable yield with COM compared to green manure treatments $(P<0.0001$, Table 4$)$. Bonus tubers, which bring a premium price, increased with COM treatment, from 15 to $71 \%$, compared to other treatments (Table 4). Contrast analysis indicated that bonus $(P=0.0016)$ and overweight marketable $(P=$ $0.0072)$ tuber classes were higher in COM compared to green manure treatments.

Not including the MUSTmeal treatment, overweight and total tuber yield decreased while bonus yield increased with PED incidence (Fig. 3a). Upon inspection of the regression plots, it is clear that the significant relationships resulted because of three treatment groupings; COM at low, SS2 at high, and other treatments at intermediate PED incidence (Fig. 3a). Regular tuber yield increased with sulfate $(P=$ $0.01)$ but the relationship was driven by the yield and very high concentration with VAP treatment (Fig. 3b) because the relationship was not significant when the treatment was removed from the data set (data not shown). Bonus yield 
Table 3 Water extractable nitrate- $\mathrm{N}\left(\mathrm{NO}_{3}{ }^{-} \mathrm{N}\right)$, sodium bicarbonate extractable-P, ammonium acetate extractable- $\mathrm{K}$, water extractable sulfate $\left(\mathrm{SO}_{4}{ }^{-2}\right)$, $\mathrm{pH}$ and electrical conductivity (EC) in soil following potato harvest

\begin{tabular}{|c|c|c|c|c|c|c|c|c|c|c|}
\hline \multirow[t]{2}{*}{ Treatment $^{\mathrm{a}}$} & \multicolumn{2}{|l|}{$\mathrm{NO}_{3}{ }^{-}-\mathrm{N}$} & \multicolumn{2}{|l|}{$\mathrm{P}$} & \multirow[t]{2}{*}{$\mathrm{K}$} & \multicolumn{2}{|l|}{$\mathrm{SO}_{4}^{-2}-\mathrm{S}$} & \multirow[t]{2}{*}{$\mathrm{pH}$} & \multicolumn{2}{|l|}{ EC } \\
\hline & \multicolumn{5}{|c|}{$\mathrm{kg} \mathrm{ha}^{-1}$} & & & & \multicolumn{2}{|l|}{$\mathrm{dS} \mathrm{m}^{-1}$} \\
\hline Control & $49 \pm 6$ & $b^{b}$ & $31 \pm 2$ & $\mathrm{~b}$ & $285 \pm 9$ & $28 \pm 2$ & b & $6.0 \pm 0.1$ & $0.19 \pm 0.01$ & $\mathrm{~b}$ \\
\hline $\mathrm{COM}$ & $73 \pm 19$ & $\mathrm{~b}$ & $65 \pm 11$ & $\mathrm{a}$ & $455 \pm 81$ & $61 \pm 9$ & $\mathrm{~b}$ & $6.7 \pm 0.2$ & $0.35 \pm 0.05$ & $a b$ \\
\hline MUSTmeal & $203 \pm 33$ & $\mathrm{a}$ & $45 \pm 9$ & $a b$ & $388 \pm 74$ & $142 \pm 28$ & $\mathrm{a}$ & $5.9 \pm 0.2$ & $0.52 \pm 0.10$ & $\mathrm{a}$ \\
\hline VAP & $66 \pm 17$ & $\mathrm{~b}$ & $31 \pm 3$ & $\mathrm{~b}$ & $307 \pm 8$ & $139 \pm 21$ & $\mathrm{a}$ & $6.1 \pm 0.1$ & $0.27 \pm 0.02$ & $a b$ \\
\hline $\mathrm{O} / \mathrm{PEA}$ & $66 \pm 9$ & $\mathrm{~b}$ & $36 \pm 2$ & $\mathrm{~b}$ & $304 \pm 10$ & $38 \pm 3$ & $\mathrm{~b}$ & $6.0 \pm 0.2$ & $0.19 \pm 0.02$ & $\mathrm{~b}$ \\
\hline CMV & $54 \pm 10$ & $\mathrm{~b}$ & $36 \pm 4$ & $\mathrm{~b}$ & $425 \pm 84$ & $42 \pm 2$ & $\mathrm{~b}$ & $6.3 \pm 0.1$ & $0.20 \pm 0.02$ & $\mathrm{~b}$ \\
\hline $\mathrm{SS} 2$ & $117 \pm 17$ & $\mathrm{~b}$ & $29 \pm 2$ & $\mathrm{~b}$ & $315 \pm 18$ & $34 \pm 3$ & $\mathrm{~b}$ & $6.1 \pm 0.1$ & $0.22 \pm 0.02$ & $\mathrm{~b}$ \\
\hline $\mathrm{SS} 1$ & $58 \pm 11$ & $\mathrm{~b}$ & $31 \pm 3$ & $\mathrm{~b}$ & $330 \pm 35$ & $47 \pm 6$ & $\mathrm{~b}$ & $6.5 \pm 0.3$ & $0.34 \pm 0.09$ & $a b$ \\
\hline RYE & $88 \pm 11$ & $\mathrm{~b}$ & $29 \pm 1$ & $\mathrm{~b}$ & $351 \pm 28$ & $36 \pm 3$ & $\mathrm{~b}$ & $6.3 \pm 0.2$ & $0.26 \pm 0.03$ & $a b$ \\
\hline MUSTor & $48 \pm 8$ & $\mathrm{~b}$ & $30 \pm 6$ & $\mathrm{~b}$ & $269 \pm 9$ & $54 \pm 13$ & $\mathrm{~b}$ & $6.4 \pm 0.2$ & $0.26 \pm 0.04$ & $a b$ \\
\hline MUSTwh & $57 \pm 4$ & $\mathrm{~b}$ & $31 \pm 3$ & $\mathrm{~b}$ & $300 \pm 15$ & $65 \pm 13$ & $\mathrm{~b}$ & $6.0 \pm 0.1$ & $0.21 \pm 0.02$ & $\mathrm{~b}$ \\
\hline ALF & $116 \pm 22$ & $\mathrm{~b}$ & $38 \pm 5$ & $\mathrm{~b}$ & $363 \pm 63$ & $41 \pm 5$ & $\mathrm{~b}$ & $6.6 \pm 0.2$ & $0.30 \pm 0.03$ & $a b$ \\
\hline$P>F^{\mathrm{c}}$ & 0.0001 & & 0.0001 & & NS & 0.0001 & & NS & 0.0016 & \\
\hline \multicolumn{11}{|c|}{ Selected contrasts (significant probability) } \\
\hline VAP vs Green manures & NS & & NS & & & $<0.0001$ & & & NS & \\
\hline COM vs Green manures & NS & & $<0.0001$ & & & NS & & & NS & \\
\hline MUSTmeal vs Green manure & $<0.0001$ & & 0.0105 & & & $<0.0001$ & & & $<0.0001$ & \\
\hline Mustards vs MUSTmeal & $<0.0001$ & & 0.0108 & & & $<0.0001$ & & & $<0.0001$ & \\
\hline Mustards vs Non-mustards & 0.0094 & & NS & & & 0.0406 & & & NS & \\
\hline
\end{tabular}

${ }^{\mathrm{a}}$ Treatments: Control=wheat-control, $\mathrm{COM}=$ compost, $\mathrm{MUST}_{\text {meal }}=$ mustard seed-meal, $\mathrm{VAP}=$ Vapam, $\mathrm{O} / \mathrm{PEA}=$ oat $/$ pea mix, $\mathrm{CMV}=\mathrm{Canada}$ milk vetch, $\mathrm{SS} 2=2$-years sorghum-sudangrass, SS1=1-year sorghum-sudangrass, RYE=fall rye, MUSTor=Oriental mustard, MUSTwh=white mustard, and $\mathrm{ALF}=$ alfalfa. Mustards=white and oriental mustard; non-mustards $=$ oat/peas mix, Canada milk vetch, 1- and 2-years Sorghum-sudangrass, fall rye and alfalfa

${ }^{\mathrm{b}}$ Values are means \pm 1 standard error. Within columns means followed by the same letter are not significantly different $(P>0.05)$ according to the Bonferroni's multiple comparison test

${ }^{\mathrm{c}}$ Treatment significant probability. NS, not significant $(P>0.05)$

decreased while overweight and total tuber yields increased with extractable-P (Fig. 3c). When the COM treatment with its high extractable- $P$ values were removed from the data set, overweight and total tuber yields still increased with soil concentrations $(\mathrm{P}<0.05)$. Tuber quality attributes (green color, rot damage, hollow heart, specific gravity, sugar end, dark end and fry color) were not related with treatments (data not shown).

Potato Early Dying was best predicted $(P=0.0076)$ by the combination of $V$. dahliae propagule density and extractable-P (Table 5, Fig. 4a). The model explained $66 \%$ of the variation in measured PED incidence. Multiple regression analysis showed total yield predicted by PED incidence, sulfate and $\mathrm{NO}_{3}{ }^{-} \mathrm{N}(P=0.0002)$. These three variables explained $92 \%$ of the variability in potato total marketable yield (Table 5). The measured and predicted total marketable yield were well related $\left(r^{2}=0.93\right)$, indicating that the model fit was good (Fig. 4b). Eighty-two percent of the variability in marketable regular tuber category was explained by the combination of sulfate, PED incidence and $\mathrm{NO}_{3}{ }^{-} \mathrm{N}$, while $86 \%$ of the variability of the marketable bonus category was predicted by PED incidence and sulfate. Finally, the overweight category was best explained by the extractable-P by $61 \%(P=0.004)$ (Table 5).

\section{Discussion}

In this study, a variety of green manure crops and organic amendments, such as mustard seed meal and composted beef cattle manure, were assessed for their ability to kill $V$. dahliae microsclerotia, to reduce PED incidence and ultimately, to increase potato yield. VAP and MUSTmeal were the most effective treatments reducing germination of buried microsclerotia within 1 week after incorporation. The efficacy of Vapam in reducing germination of microsclerotia depends on its conversion in the soil to very active and toxic ITC compounds, particularly methyl-isothiocyanate (methylITC), which constitutes $90 \%$ of the conversion products in soil (Leistra et al. 1974). The suppressive activity of the 

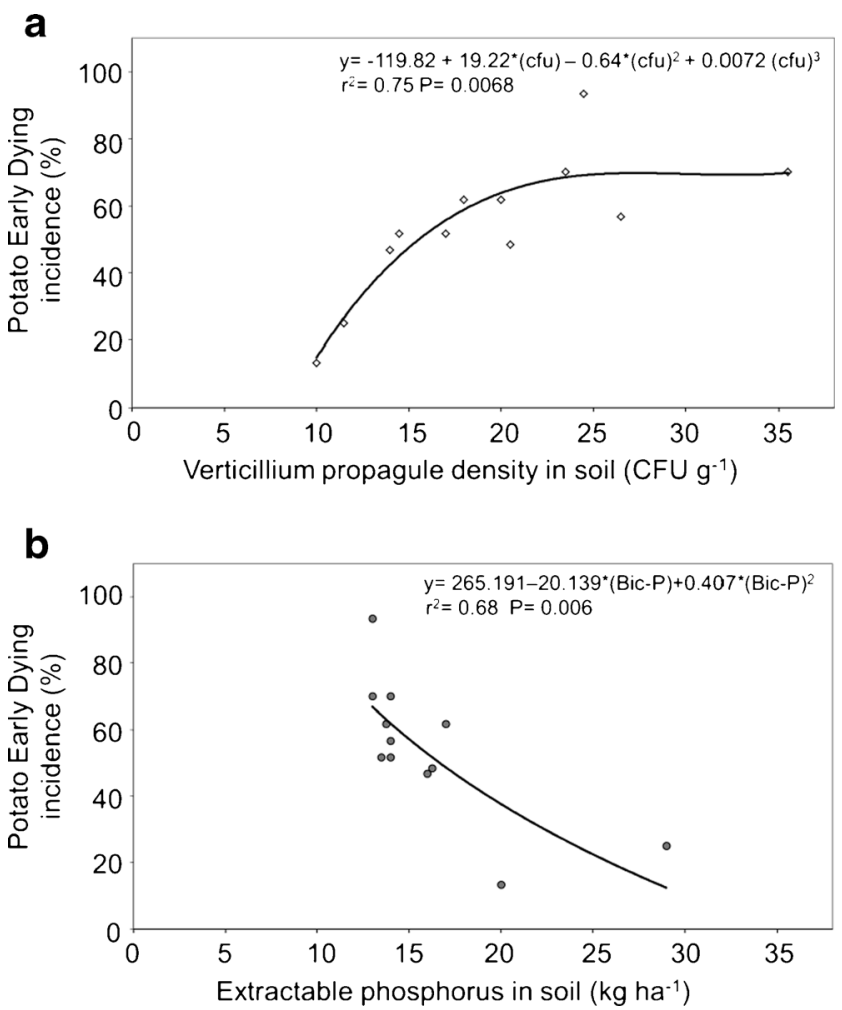

Fig. 2 Relationship between incidence (foliar symptoms) of Potato Early Dying and: a propagule density of Verticillium dahliae in soil, and $\mathbf{b}$ extractable phosphorus in soil after potato harvest

MUSTmeal treatment may be associated with the presence of GLS hydrolysis products as well. Partially deoiled mustard seed meal contained sinigrin-GLS, which transformed to 2propenyl isothiocyanate (2-propenyl-ITC). 2-propenyl-ITC is one of the most biologically active forms of ITCs, and it has been shown to kill soil pathogens like $V$. dahliae (Olivier et al. 1999). Although MUSTmeal treatment reduced the germination of buried microsclerotia 1 week after incorporation, the germination was higher 3 weeks after incorporation. The findings reported here provide evidence that exposure to sub-lethal concentrations of ITC sufficiently weaken microsclerotia that they do not germinate on selective media. Once the ITC concentration dissipated in soil, microsclerotia regained the ability to grow on the plate medium. It is common that some organisms weakened by sub-lethal treatments remain viable but not culturable, which means that some cells will require special stimuli to return to the culturable state (Weichart and Kjelleberg 1996). This condition is often observed in injured organisms, which fail to grow under selective isolation conditions. However, when injured organisms are removed from the sublethal conditions, the microorganisms restore their ability to grow in culture (Weichart and Kjelleberg 1996). For example, exposure of microsclerotia to sub-lethal concentrations of liquid swine manure (LSM) or volatile fatty acids (VFA) (Tenuta et al. 2002), $\mathrm{NH}_{3}$ and $\mathrm{HNO}_{2}$ (Tenuta and Lazarovits 2002a, 2004) followed by immediate plating onto germination medium resulted in a lower germination of microsclerotia. However, placement of the microsclerotia in soil free of LSM, VFA, $\mathrm{NH}_{3}$ or $\mathrm{HNO}_{2}$ for 7 days allowed the organism to recover, resulting in a moderate rebound of germination of microsclerotia. Smolinska et al. (2003) found that $F$. oxysporum isolates exposed to low concentrations of pure 2-propeny-ITC $(0.3 \mu \mathrm{l})$ for $24 \mathrm{~h}$ did not grow on plate medium until the medium was cleared of ITCs. Our result suggests that fungitoxicity of ITCs could be induced by increasing concentration or exposure time of microsclerotia to ITCs.

MUSTwh, MUSTor and O/PEA green manure treatments inhibited germination of buried microsclerotia to $60 \%$ of the control. These green manures show some promise as a means to reduce $V$. dahliae propagule density in soil. Reduction in germination of $V$. dahliae microsclerotia has been observed with several green manures (Lopez-Escudero et al. 2007). Brassicaceae green manure crops have been used to reduce soil populations of $V$. dahliae and incidence of Verticillium wilt in potato (Rowe and Powelson 2002) due to the release of ITCs. The efficacy of Brassicaceae green manures to kill the pathogen depends on the concentration of ITC released from the plant material (shoot or roots tissue or seed meal) (Olivier et al. 1999). The most important factor limiting ITC concentration in soil may not be GLS concentration in the amendment itself, but release of ITC from the amendment to the soil. High release of ITC in soil occurs when cell membranes are broken (Gimsing and Kirkegaard 2009). The level of plant physical disruption necessary to maximize ITC is generally impossible with green manure crops (Matthiessen and Kirkegaard 2006). However, such a limitation does not exist when using seed meal since the seed crushing procedure results in extensive cellular disruption (Brown and Morra 2005). Therefore, the concentration of ITCs released by the mustard seed meal may be 10 times higher than from intact vegetative plant tissue (roots and aerial parts) (Brown and Morra 2005; Kirkegaard et al. 1996). Further, the effectiveness of ITCs release from Brassicaceae green manure crops improves with lower organic matter content of soil (Matthiessen and Kirkegaard 2006). The organic matter content of the loam soil in the current study was $51 \mathrm{~g} \mathrm{~kg}^{-1}$ whereas Brassicaceae green manures are recommended for sand soils of relatively lower organic matter content than the soil used here (Matthiessen and Kirkegaard 2006). In a laboratory study, doubling the fresh matter addition of MUSTor from 34.5 to $69 \mathrm{Mg} \mathrm{ha}^{-1}$ equivalent to the same soil used in this current study was not more lethal to $V$. dahliae microscleroatia buried in soil (Molina 2009). Even at that double addition rate of MUSTor, less than half the amount of 2-propenyl-isothiocyanate was produced than seed-meal applied at the rate of this current study. Therefore, we hypothesize that the higher concentration of ITCs released by the MUSTmeal was responsible for greater death of buried $V$. dahliae microsclerotia in soil.

The Verticillium propagule density in soil prior to planting was $13 \mathrm{cfu} \mathrm{g}^{-1}$ soil and $20 \mathrm{cfu} \mathrm{g}^{-1}$ soil at harvest across all 
Table 4 Effect of green manure, organic amendments and Vapam treatment on marketable potato yield

\begin{tabular}{|c|c|c|c|c|c|c|c|}
\hline \multirow[t]{2}{*}{ Treatment $^{\mathrm{a}}$} & \multicolumn{7}{|c|}{ Marketable yield $\left(\mathrm{Mg} \mathrm{ha}^{-1}\right)^{\mathrm{b}}$} \\
\hline & Regular & Bonus & & Overweig & & Total & \\
\hline Control & $11.0 \pm 0.9^{\mathrm{c}}$ & $16.1 \pm 1.1$ & $a b^{\S}$ & $3.7 \pm 1.3$ & $a b$ & $30.8 \pm 1.6$ & $\mathrm{~b}$ \\
\hline $\mathrm{COM}$ & $10.5 \pm 0.9$ & $19.5 \pm 2.1$ & a & $8.7 \pm 1.8$ & $\mathrm{a}$ & $38.7 \pm 1.3$ & $\mathrm{a}$ \\
\hline MUSTmeal & $8.9 \pm 0.4$ & $14.0 \pm 1.3$ & $a b$ & $4.3 \pm 0.6$ & $a b$ & $27.2 \pm 1.8$ & $\mathrm{~b}$ \\
\hline VAP & $13.3 \pm 1.0$ & $16.6 \pm 1.1$ & $a b$ & $3.2 \pm 1.0$ & $a b$ & $33.1 \pm 1.6$ & $a b$ \\
\hline $\mathrm{O} / \mathrm{PEA}$ & $9.5 \pm 0.8$ & $16.9 \pm 0.8$ & $a b$ & $5.9 \pm 1.4$ & $a b$ & $32.3 \pm 1.2$ & $a b$ \\
\hline CMV & $10.9 \pm 0.3$ & $15.2 \pm 0.9$ & $a b$ & $6.0 \pm 1.4$ & $\mathrm{ab}$ & $32.0 \pm 0.3$ & $a b$ \\
\hline $\mathrm{SS} 2$ & $11.7 \pm 0.3$ & $11.4 \pm 1.2$ & $\mathrm{~b}$ & $2.9 \pm 1.6$ & $\mathrm{~b}$ & $26.0 \pm 1.6$ & $\mathrm{~b}$ \\
\hline $\mathrm{SS} 1$ & $11.1 \pm 1.3$ & $14.8 \pm 1.2$ & $a b$ & $4.9 \pm 0.4$ & $a b$ & $30.8 \pm 2.3$ & $\mathrm{~b}$ \\
\hline RYE & $11.0 \pm 0.9$ & $14.5 \pm 1.6$ & $\mathrm{ab}$ & $5.6 \pm 1.7$ & $\mathrm{ab}$ & $31.2 \pm 2.6$ & $\mathrm{ab}$ \\
\hline MUSTor & $11.7 \pm 1.4$ & $15.5 \pm 1.5$ & $\mathrm{ab}$ & $3.5 \pm 1.0$ & $a b$ & $30.6 \pm 1.4$ & $\mathrm{~b}$ \\
\hline MUSTwh & $11.7 \pm 0.8$ & $15.4 \pm 1.1$ & $a b$ & $5.4 \pm 0.9$ & $\mathrm{ab}$ & $32.6 \pm 1.7$ & $a b$ \\
\hline ALF & $10.1 \pm 0.4$ & $15.4 \pm 0.9$ & $a b$ & $7.2 \pm 0.9$ & $\mathrm{ab}$ & $32.6 \pm 1.2$ & $\mathrm{ab}$ \\
\hline$P>F^{\mathrm{d}}$ & NS & 0.0321 & & 0.0365 & & 0.0003 & \\
\hline \multicolumn{8}{|c|}{ Selected contrasts (significant probability) } \\
\hline \multicolumn{2}{|c|}{ Control vs Green manures } & \multicolumn{2}{|l|}{$\mathrm{NS}^{\mathrm{y}}$} & \multicolumn{2}{|l|}{ NS } & \multicolumn{2}{|l|}{ NS } \\
\hline \multicolumn{2}{|c|}{ VAP vs Green manures } & \multicolumn{2}{|l|}{ NS } & \multicolumn{2}{|l|}{ NS } & \multicolumn{2}{|l|}{ NS } \\
\hline \multicolumn{2}{|c|}{ COM vs Green manures } & \multicolumn{2}{|l|}{0.0016} & \multicolumn{2}{|l|}{0.0072} & \multicolumn{2}{|l|}{$<0.0001$} \\
\hline \multicolumn{2}{|c|}{ MUSTmeal vs Green manure } & \multicolumn{2}{|l|}{ NS } & \multicolumn{2}{|l|}{ NS } & \multicolumn{2}{|l|}{0.0200} \\
\hline \multicolumn{2}{|c|}{ Mustards vs MUSTmeal } & \multicolumn{2}{|l|}{ NS } & \multicolumn{2}{|l|}{ NS } & \multicolumn{2}{|l|}{0.0201} \\
\hline \multicolumn{2}{|c|}{ Mustards vs Non-mustards } & \multicolumn{2}{|l|}{ NS } & \multicolumn{2}{|l|}{ NS } & \multicolumn{2}{|l|}{ NS } \\
\hline
\end{tabular}

${ }^{\mathrm{a}}$ Treatments: Control=wheat-control, $\mathrm{COM}=$ compost, $\mathrm{MUST}_{\text {meal }}=$ mustard seed-meal, $\mathrm{VAP}=\mathrm{Vapam}, \mathrm{O} / \mathrm{PEA}=\mathrm{oat} /$ pea $\mathrm{mix}, \mathrm{CMV}=\mathrm{Canada}$ milk vetch, $\mathrm{SS} 2=2$-years sorghum-sudangrass, SS1=1-year sorghum-sudangrass, RYE=fall rye, MUSTor=Oriental mustard, MUSTwh=white mustard, and $\mathrm{ALF}=$ alfalfa. Mustards=white and oriental mustard; non-mustards=oat/peas mix, Canada milk vetch, 1- and 2-years sorghum-sudangrass, fall rye and alfalfa

${ }^{\mathrm{b}}$ Potato tubers graded into weight categories for marketable yield: regular 86-170 g, bonus 170.1-340 $\mathrm{g}$ and overweight $>340 \mathrm{~g}$

${ }^{\mathrm{c}}$ Value are means \pm standard error. Within columns means followed by the same letter are not significantly different $(P>0.05)$ according to the Bonferroni's multiple comparison test

${ }^{\mathrm{d}}$ Treatment significant probability. NS, not significant $(P>0.05)$

treatments. There are no economic threshold guidelines for Verticillium in soil for Manitoba or the Prairie Provinces of Canada. Greater than $12 \mathrm{cfu} \mathrm{g}^{-1}$ soil is a guideline in Ontario for a high risk of disease and need for control measures (University of Guelph Laboratory Services, Agricultural and Food Laboratory). Disease incidence in the current study ranged from 13 to $93 \%$ indicating sufficient presence of the pathogen to potentially limit yields.

In general, green manure crops did not reduce the germination of microsclerotia or propagule density of $V$. dahliae in soil, compared to the control. Some green manure treatments such as RYE and SS2 increased propagule density as well as PED incidence. The lack of effect of the green manure treatments to reduce propagule density of $V$. dahliae and PED incidence may be due to several factors such as too small number of green manure cycles (Rowe and Powelson 2002) or insufficient physical disruption of plant tissue during plow down that lead to low release of toxic compounds (Morra and Kirkegaard 2002). These factors are relatively important for long-term survival structures of plant pathogens in soil, particularly, microsclerotia of $V$. dahliae (Rowe and Powelson 2002). These results are consistent with those of Davis et al. (1996) who reported that two consecutive years of sudangrass, oat, or rye green manure did not reduce inoculum of $V$. dahliae. Green manure crops can reduce density of propagules in soil and Verticillium wilt incidence in potato (LopezEscudero et al. 2007; Ochiai et al. 2008). Three consecutive years of green manure may be required to reduce $V$. dahliae levels in soil depending the type of green manure crop (Davis et al. 1996; Rowe and Powelson 2002). However, 3 years of green manure cropping is usually not feasible for potato production especially with current favourable returns for grain and oilseed rotation crops.

Although buried microsclerotia partially restored their ability to germinate 3 weeks after incorporation of MUSTmeal, germination was reduced by $50 \%$. Moreover, PED incidence and propagule density of $V$. dahliae were effectively reduced by MUSTmeal. It can be hypothesized that ITCs could reduce 
Fig. 3 Relationship between the potato tuber weight categories of marketable yield $\left(\mathrm{Mg} \mathrm{ha}^{-1}\right)$, regular (86-169 g), bonus (170$340 \mathrm{~g})$ and overweight $(>340 \mathrm{~g})$, and total yield and: a Potato Early Dying incidence (\%), b Water extractable sulfate $\left(\mathrm{kg} \mathrm{S} \mathrm{ha}^{-1}\right)$, and $\mathbf{c}$ Extractable phosphorus in soil $\left(\mathrm{kg} \mathrm{P} \mathrm{ha}^{-1}\right)$. MUSTmeal treatment was not taken in consideration due to the possible negative effects of excess of $\mathrm{N}$ incorporated with the mustard seed-meal. Non significant (NS) at $P>0.05 .(n=11)$
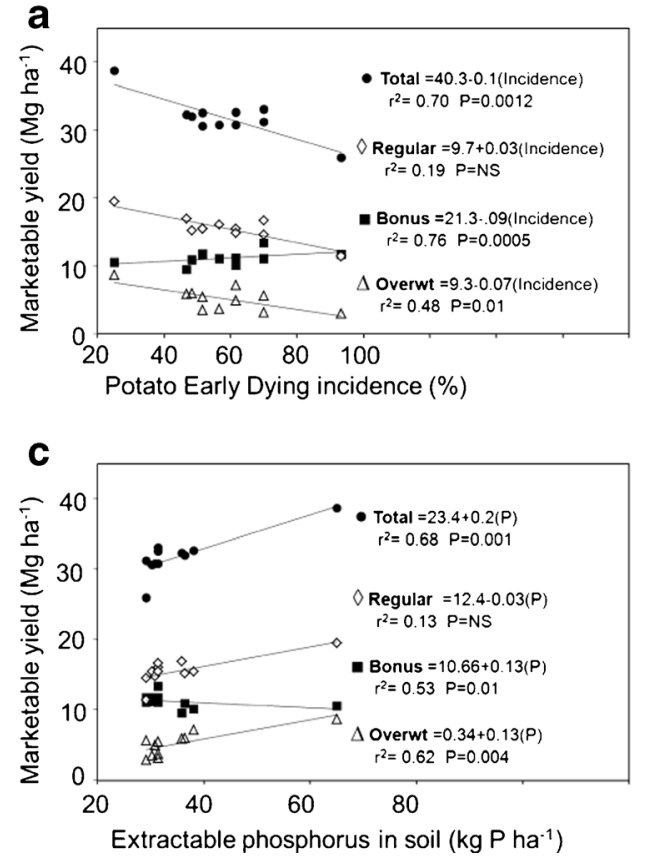

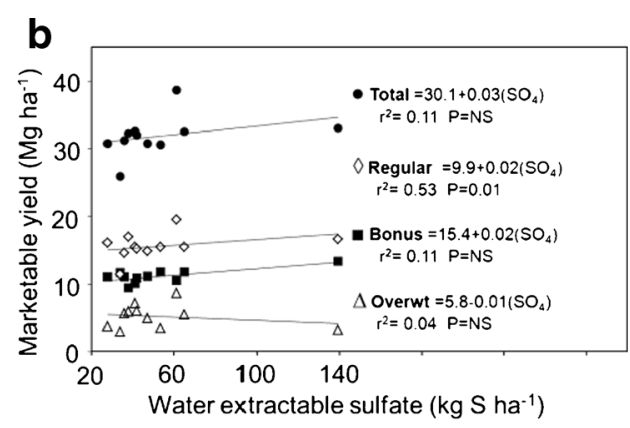

\section{.}

indirectly by influencing the indigenous microbial population through compounds released directly from the meal upon application to soil or during decomposition of the meal. For example, Njoroge et al. (2008) detected ITCs in soil amended with mustard materials and observed increased population

germination of microsclerotia, as well as $V$. dahliae propagule concentration in soil. Besides the toxicity of GLS hydrolysis products (Brown and Morra 1997), the mechanisms by which mustard green manures and seed meals may suppress soilborne pathogens are varied and often unknown (Wiggins and Kinkel 2005a). MUSTmeal may reduce propagule density densities of fluorescent pseudomonads, an antifungal bacteria

Table 5 Multiple-regression models that best predict Potato Early Dying incidence and potato marketable yield

\begin{tabular}{|c|c|c|c|c|c|c|}
\hline Variable & Response & Variable & $\mathrm{R}^{2}$ & P-value & Coefficient & Intercept \\
\hline \multicolumn{7}{|c|}{ Potato Early Dying $(n=12)$} \\
\hline \multirow[t]{2}{*}{ Incidence } & Partials & $\begin{array}{l}\text { V. dahliae }{ }^{\mathrm{a}}\left(\mathrm{cfu} \mathrm{g}^{-1}\right) \\
\text { Extractable-P }\left(\mathrm{Kg} \mathrm{ha}^{-1}\right)\end{array}$ & $\begin{array}{l}0.53 \\
0.13\end{array}$ & $\begin{array}{l}0.0071 \\
0.09\end{array}$ & $\begin{array}{r}1.384 \\
-0.901\end{array}$ & \\
\hline & Model & & 0.66 & 0.0076 & & 59.571 \\
\hline \multicolumn{7}{|c|}{ Potato marketable Yield $\left(n=11^{\mathrm{b}}\right)$} \\
\hline \multirow[t]{3}{*}{ Total yield } & Partials & $\begin{array}{l}\text { Disease incidence }(\%) \\
\text { Sulfate }\left(\mathrm{kg} \mathrm{ha}^{-1}\right)\end{array}$ & $\begin{array}{l}0.70 \\
0.12\end{array}$ & $\begin{array}{l}0.0012 \\
0.046\end{array}$ & $\begin{array}{c}-0.182 \\
0.04\end{array}$ & \\
\hline & & $\mathrm{NO}_{3}^{-}\left(\mathrm{kg} \mathrm{ha}^{-1}\right)$ & 0.10 & 0.016 & 0.046 & \\
\hline & Model & & 0.92 & 0.0002 & & 36.9 \\
\hline \multicolumn{7}{|c|}{ Tuber categories $^{\mathrm{c}}$} \\
\hline \multirow[t]{2}{*}{ Regular } & Partials & $\begin{array}{l}\text { Sulfate }\left(\mathrm{kg} \mathrm{ha}^{-1}\right) \\
\text { Disease incidence (\%) }\end{array}$ & $\begin{array}{l}0.53 \\
0.18\end{array}$ & $\begin{array}{l}0.01 \\
0.05\end{array}$ & $\begin{array}{l}0.015 \\
0.037\end{array}$ & \\
\hline & Model & $\mathrm{NO}_{3}^{-}\left(\mathrm{kg} \mathrm{ha}^{-1}\right)$ & $\begin{array}{l}0.10 \\
0.82\end{array}$ & 0.08 & 0.021 & 8.99 \\
\hline \multirow[t]{2}{*}{ Bonus } & Partials & $\begin{array}{l}\text { Disease incidence }(\%) \\
\text { Sulfate }\left(\mathrm{kg} \mathrm{ha}^{-1}\right)\end{array}$ & $\begin{array}{l}0.75 \\
0.11\end{array}$ & $\begin{array}{l}0.0005 \\
0.029\end{array}$ & $\begin{array}{r}-0.098 \\
0.021\end{array}$ & \\
\hline & Model & & 0.86 & 0.0003 & & 20.152 \\
\hline \multirow[t]{2}{*}{ Overweight } & Partials & Extractable-P (kg ha $\left.{ }^{-1}\right)$ & 0.61 & 0.0042 & 0.1363 & \\
\hline & Model & & 0.61 & 0.004 & & 0.348 \\
\hline
\end{tabular}

${ }^{\mathrm{a}}$ Inoculum density at harvest

${ }^{\mathrm{b}}$ MUSTmeal treatment was not included in this analysis due to possible negative effects on potato growth after excess of $\mathrm{N}$ incorporated with the mustard seed meal

${ }^{\mathrm{c}}$ Potato tubers graded into weight categories for marketable yield: regular 86-169 g, bonus 170-340 g and overweight $>340 \mathrm{~g}$ 

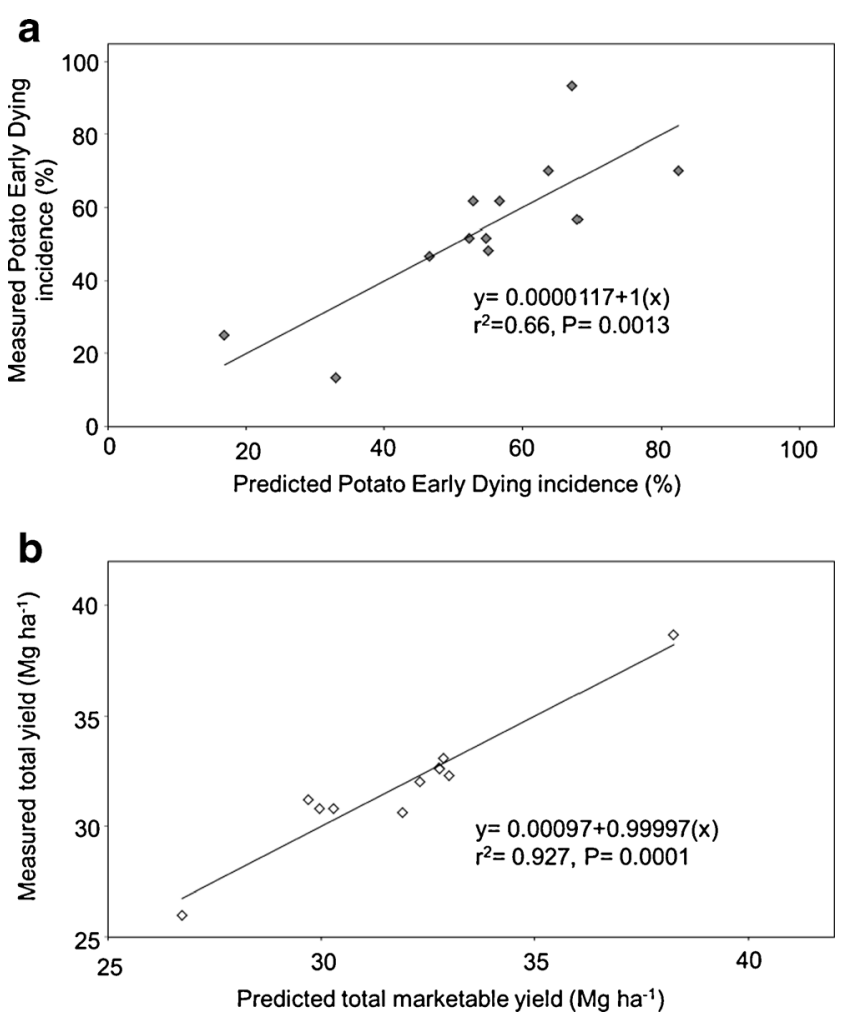

Fig. 4 a Relationship between Potato Early Dying incidences predicted by multiple linear models given in Table 5, and measured Potato Early Dying incidence for green manures, composted cattle, seed meal, Vapam, and control treatments $(n=12)$. b Relationship between total marketable potato yield predicted by multiple linear models given in Table 5 and measured total marketable potato yield for green manure, composted cattle, Vapam, and control treatments. MUSTmeal treatment was not taken in consideration due to the possible negative effects of excess of $\mathrm{N}$ incorporated with the mustard seed-meal. $(n=11)$

antagonist against $V$. dahliae (Pegg and Brady 2002). Incorporation of mustard seed meals significantly increased populations of Streptomyces spp (Cohen et al. 2005), which were associated with reduction of $V$. dahliae (Krechel et al. 2002). This mechanism of control could explain the consistent reduction of propagule density observed before and after the potato season in plots amended with mustard seed meal.

The application of Vapam reduced propagule density of $V$. dahliae at the beginning of the potato season in 2008 . However, severe incidence of PED was observed on potato, as well as an increased number of propagules by immediately after potato harvest of the Vapam treatment. Disease plant residues would not have had time to decompose and release microsclerotia. The biocidal activity of Vapam is provided by methyl isothiocyanate (methyl-ITC) (Gerstl et al. 1977), a very active ITC with high vapour pressure $(16.0 \mathrm{mmHg}$ at $20{ }^{\circ} \mathrm{C}$ ), and thereby elevated potential for volatilization (Zheng et al. 2006). The lack of control in this case could be associated with the lower application rate compared to maximum rates used in potato growing regions in the US, $752 \mathrm{~L} \mathrm{ha}^{-1}$ this study compared to $935 \mathrm{~L} \mathrm{ha}^{-1}$, and the low concentration of active ingredient ( $32.7 \%$ a.i.) used compared to other commercial formulations of Vapam (37 and $42 \%$ a.i.). Additionally, the lack of efficacy is possibly due to the volatilization loss of methyl-ITC in the upper soil profile, where a large amount of wheat residues may prevent proper sealing of the soil, allowing methyl-ITCs to escape to the atmosphere. Optimum distribution of methyl-ITC in soil for the control of pathogens is rarely achieved with current application practices (Duniway 2002). Soil sealing using irrigation may prevent volatilization of methyl-ITC after application of Vapam. Particularly in cold climates such as Manitoba, producers flush the water out of irrigation equipment after harvest before the onset of freezing temperatures, thus proper soil sealing using irrigation water may not be possible after Vapam application.

Composted materials have been effective for reducing Verticillium wilt of potato in a previous study (Entry et al. 2005). In this study, composted cattle manure reduced incidence of PED and maintained low propagule density of $V$. dahliae in soil. Organic soil amendments might be responsible for changes in soil properties that may disrupt the ability of $V$. dahliae to recognize a potential host, and for the propagules to germinate, grow, or colonize a host (Ochiai et al. 2008). Davis et al. (1990) suggested that reduction of Verticillium wilt may be mediated by improved soil fertility, particularly by optimum available phosphorus in soil. Compost can improve plant health due to the increase of soil nutrient concentration and improvement of soil physicochemical properties (Corti et al. 1998). Composted soil amendments can build a pathogen suppressive soil environment, where biological control is promoted through antagonism, microbial competition, hyperparasitism and antibiosis (Hoitink and Fahy 1986). Kuter et al. (1983) reported reduction of propagule density of $R$. solani in soil amended with composted cattle manure due to enhanced activity of antagonistic microorganism populations. Our results suggest that reduction of PED incidence with compost is not necessarily dependent on reduction of propagule density of $V$. dahliae.

Potato production systems in which organic amendments are applied to soil can improve soil nutrient availability, soil tilth, water holding capacity and plant health (LaMondia et al. 1999; Stark and Porter 2005). In this study, the composted cattle manure (COM) significantly increased marketable potato yield, and neither VAP nor any of the green manure treatments resulted in improvement of marketable yield compared with the control treatment. In addition, only the COM treatment yield $\left(38.7 \mathrm{Mg} \mathrm{ha}^{-1}\right)$ was higher than the control treatment $\left(30.8 \mathrm{Mg} \mathrm{ha}^{-1}\right)$. This increment represents a considerable improvement in potato yield compared to the production average for Manitoba (31.4 $\mathrm{Mg} \mathrm{ha}^{-1}$ ) (Agriculture and Agri-Food Canada 2007).

Soil amendment with composted materials delays decline of photosynthesis in leaves that expand early in the season, 
increasing the number of leaves and leaf area (Gent et al. 1999) and ultimately, reducing yield losses caused by PED (LaMondia et al. 1999). By this mechanism compost may help potato to defend against the detrimental effect of PED, which is believed to decrease leaf surface area as well as photosynthesis of the plant and ultimately, the supply of assimilates required for later tuber bulking growth (Bowden and Rouse 1991). The factors most closely associated with higher bonus marketable yield were sulfate and disease incidence. Although, extractable-P and extractable-K were not found directly related to the increase of bonus marketable yield, both have been previously reported as the most obvious causes of increased production of larger tubers and total yield, respectively (Moore et al. 2011). Furthermore, the increase in late bulking growth is not just a crop response to better soil nutrient status, it may also be related to the lower disease incidence that was found associated with the soil nutrient increase as well. Optimum nutrient uptake for potato yield is associated with reduced PED incidence as well (Lambert et al. 2005).

Disease suppression by compost was associated with increased microbial activity as well as changes in concentration of N, P, Ca, and soil organic matter of treated soils (Hoitink and Fahy 1986). Increased soil organic matter has been associated with reduction of potato PED incidence in North America (Briar et al. 2009; Davis et al. 2010a). Compost amendments are a source of organic carbon, and when added to the soil should increase soil organic carbon (Magdoff and Weil 2004; Zinati et al. 2001). In this study, the carbon applied with composted beef cattle manure was equivalent to an addition of $1.4 \%$ of total soil mass. Based on a survey of 23 commercial fields, of Russet Burbank potato, increasing soil organic carbon levels was related to decreasing incidence of PED ( $r=-0.7$; Tenuta et al., unpublished). On average, soil organic carbon levels $>2.8 \%$ had PED incidence levels less than $20 \%$. Increased organic matter has been reported as one of the major factors in soil associated with the reduction of inoculum density and PED in commercial potato fields in Idaho (Davis et al. 2001). Although, the mechanism involved in the suppression is unclear, the addition of compost may impact the carbon energy available for microorganisms in soil (Weil and Magdoff 2004). Thus, pathogen survival may be reduced by increased microbial activity (Hoitink and Fahy 1986) or presence of biologically active substances from residues and soil microbiota (Lazarovits 2010).

In this study, not all treatments which reduced disease incidence and number of propagules in the soil resulted in increased potato yield. Despite the reduced germination of microsclerotia and reduced density of propagules in soil, the MUSTmeal treatment did not increase potato yield. Incorporation of the mustard seed meal led to significantly higher concentration of $\mathrm{N}$ in soil $\left(203 \mathrm{~kg} \mathrm{~N} \mathrm{ha}^{-1}\right)$, but did not significantly increase extractable-P concentration. Mazzola et al. (2007) documented that mustard seed meal usually contains from 5.5 to $6.8 \% \mathrm{~N}$. Therefore, mustard meal added at $9,000 \mathrm{~kg} \mathrm{ha}^{-1}$ added approximately $281 \mathrm{~kg} \mathrm{~N} \mathrm{ha}^{-1}$. In this study, this $\mathrm{N}$ content of seed meal was not taken into account to reduce fertilizer application rates. $\mathrm{N}$ in seed meal likely led to more vegetative growth and less tuber development. Adequate management of $\mathrm{N}$ is critical for optimal potato yield (Sincik et al. 2008), whereas excessive available $\mathrm{N}$ results in reduced yields (Lauer 1986; Neeteson and Zwetsloot 1989).

The findings of this study indicate that incorporation of composted beef cattle manure to potato fields planted to the susceptible cv Russet Burbank increases potato yield, decreases PED incidence, and improves nutrient availability. It is hypothesized that improvement of nutrient availability and soil organic matter is possibly involved. Further examination of the mechanisms involved and factors controlling the suppressive activity of compost against PED are required.

One or two years of green manure seem to be ineffective in reducing PED in Manitoba. However, the results of this study suggest that oriental mustard, white mustard and oat/peas mix green manures have potential to reduce germination of $V$. dahliae and soil propagule densities. Therefore, multiple years of green manure may be needed to reduce PED in potato field of Manitoba. Addition of oriental mustard seed meal has the potential to be an important part of PED management program in Manitoba but current high commodity prices may limit use.

The role of mustard seed meal in nutrient management programs needs further investigation for growers who seek a nonchemical alternative to fumigation. However, critical issues remain which must be addressed before mustard seed meal can be considered a viable option. For example, the rates used in this study would be economically unaffordable for potato producers; therefore, it is necessary to investigate whether lower application rates can achieve the desired control of disease.

Acknowledgments We sincerely thank Dr. Maria Antonia Henriquez for reviewing this manuscript. We thank Dr. Tracy Shinners-Carnelley for her comments and inputs on this study. Assistance with several aspects of this study from the staff from The Canada Manitoba Crop Diversification Centre as well as Lorne Adam, Trevor Fraser and Brad Sparling from the University of Manitoba are gratefully appreciated.

Open Access This article is distributed under the terms of the Creative Commons Attribution License which permits any use, distribution, and reproduction in any medium, provided the original author(s) and the source are credited.

\section{References}

Agriculture and Agri-Food Canada. 2007. Canadian potato situation and trends 2006-2007. Ottawa: Agriculture and Agri-Food Canada.

Bowden, R.L., and D.I. Rouse. 1991. Effects of Verticillium dahliae on gas exchange of potato. Phytopathology 81: 293-301. 
Briar, S., M. Tenuta, T. Shinners-Carnelley, A. Mahran, and F. Daayf. 2009. Association of soil properties, Verticillium propagules, and plant-parasitic nematodes with potato early dying in commercial fields in Manitoba. Canadian Journal of Plant Pathology-Revue Canadienne De Phytopathologie 31: 478-478.

Brown, P.D., and M.J. Morra. 1997. Control of soil-borne plant pests using glucosinolate-containing plants. Advances in Agronomy 61: $167-231$

Brown, J., and M.J. Morra. 2005. Glucosinolate-containing seed meal as a soil amendment to control plant pests 2000-2002. Subcontract Report. Moscow: University of Idaho.

Cohen, M.F., H. Yamasaki, and M. Mazzola. 2005. Brassica napus seed meal soil amendment modifies microbial community structure, nitric oxide production and incidence of Rhizoctonia root rot. Soil Biology and Biochemistry 37: 1215-1227.

Collins, H.P., A. Alva, R.A. Boydston, R.L. Cochran, P.B. Hamm, A. McGuire, and E. Riga. 2005. Soil microbial, fungal, and nematode responses to soil fumigation and cover crops under potato production. Biology and Fertility of Soils 42: 247-257.

Conn, K.L., and G. Lazarovits. 1999. Impact of animal manures on Verticillium wilt, potato scab, and soil microbial populations. Canadian Journal of Plant Pathology 21: 81-92.

Corti, C., L. Crippa, P.L. Geneveni, and M. Centemero. 1998. Compost use in plant nurseries: hydrological and physicochemical characteristics. Compost Science and Utilization 6: 35-45.

Davis, J.R., L.H. Sorensen, J.C. Stark, and D.T. Westermann. 1990. Fertility and management practices to control Verticillium wilt of the Russet Burbank potato. American Journal of Potato Research 67: 55-65.

Davis, J.R., O.C. Huisman, D.T. Westermann, S.L. Hafez, D.O. Everson, L.H. Sorensen, and A.T. Schneider. 1996. Effects of green manures on Verticillium wilt of potato. Phytopathology 86: 444-453.

Davis, J.R., O.C. Huisman, D.O. Everson, L.H. Sorensen, and A. Schneider. 1999. Control of Verticillium wilt of the Russet Burbank potato with corn and barley. (Abstr.). American Journal of Potato Research 76: 367.

Davis, J.R., O.C. Huisman, D.O. Everson, and A.T. Schneider. 2001. Verticillium wilt of potato: a model of key factors related to disease severity and tuber yield in Southeastern Idaho. American Journal of Potato Research 78: 291-300.

Davis, J.R., O.C. Huisman, D.O. Everson, P. Nolte, L.H. Sorenson, and A.T. Schneider. 2010a. Ecological relationships of Verticillium wilt suppression of potato by green manures. American Journal of Potato Research 87: 315-326.

Davis, J.R., O.C. Huisman, D.O. Everson, P. Nolte, L.H. Sorenson, and A.T. Schneider. 2010b. The suppression of Verticillium wilt of potato using corn as a green manure. American Journal of Potato Research 87: 195-208.

Duniway, J.M. 2002. Status of chemical alternatives to methyl bromide for pre-plant fumigation of soil. Phytopathology 92: 1337-1343.

Entry, J.A., C.A. Strausbaugh, and R.E. Sojka. 2005. Compost amendments decrease Verticillium dahliae on potato. Compost Science and Utilization 13: 43-49.

Fageria, N.K. 2007. Green manuring in crop production. Journal of Plant Nutrition 30: 691-719.

Gent, M.P.N., J.A. LaMondia, F.J. Ferrandino, W.H. Elmer, and K.A. Stoner. 1999. The influence of compost amendment or straw mulch on the reduction of gas exchange in potato by Verticillium dahliae and Pratylenchus penetrans. Plant Disease 83: 371-376.

Gerstl, Z., U. Mingelgrin, and B. Yaron. 1977. Behavior of Vapam and methylisothiocyanate in soils. Soil Science Society of America Journal 41: 545-548.

Gimsing, A.L., and J.A. Kirkegaard. 2009. Glucosinolates and biofumigation: fate of glucosinolates and their hydrolysis in soil. Phytochemistry Review 8: 299-310.
Hawke, M.A., and G. Lazarovits. 1994. Production and manipulation of individual microsclerotia of Verticillium dahliae for use in studies of survival. Phytopathology 84: 883-890.

Hoitink, H.A.J., and P.C. Fahy. 1986. Basis for the control of soilborne plant pathogens with compost. Annual Review of Phytopathology 24: 93-114.

Huisman, O.C., and L.J. Ashworth. 1976. Influence of crop rotation on the survival of Verticillium albo-atrum in soils. Phytopathology 66: 978-981.

Kirkegaard, J.A., P.T.W. Wong, and J.M. Desmarchelier. 1996. In vitro suppression of fungal root pathogens of cereals by Brassica tissues. Plant Pathology 45: 593-603.

Krechel, A., A. Faupel, J. Hallmann, A. Ulrich, and G. Berg. 2002. Potato-associated bacteria and their antagonistic potential towards plant-pathogenic fungi and the plant-parasitic nematode Meloidogyne incognita (Kofoid \& White) Chitwood. Canadian Journal of Microbiology 48: 772-786.

Kuter, G.A., E.B. Nelson, and H.A.J. Hoitink. 1983. Effects of fungal antagonists and compost age on suppression of Rhizoctonia damping-off in container media amended with composted hardwood bark. Phytopathology 73: 1457-1462.

Lambert, D.H., M.L. Powelson, and W.R. Stevenson. 2005. Nutritional interactions influencing diseases of potato. American Journal of Potato Research 82: 309-319.

LaMondia, J.A., F.J. Ferrandino, W.H. Elmer, and K.A. Stoner. 1999. Effect of compost amendment or straw mulch on Potato Early Dying disease. Plant Disease 83: 361-366.

Lauer, D.A. 1986. Russet Burbank yield response to sprinkler-applied nitrogen fertilizer. American Potato Journal 63: 61-69.

Lazarovits, G. 2010. Managing soilborne disease of potatoes using ecologically based approaches. American Journal of Potato Research 87: 401-411.

Leistra, M., J.M. Smelt, and H.M. Nollen. 1974. Concentration relation for methylisothiocyanate in soil after injection of metam-sodium. Pesticide Science 5: 409-417.

Lopez-Escudero, F.J., C. Mwanza, and M.A. Blanco-Lopez. 2007. Reduction of Verticillium dahliae microsclerotia viability in soil by dried plant residues. Crop Protection 26: 127-133.

Magdoff, F., and R.R. Weil. 2004. Soil organic matter management strategies. In Soil organic matter in sustainable agriculture, ed. F. Magdoff and R.R. Weil, 45-66. Boca Raton: CRC Press.

Matthiessen, J.N., and J.A. Kirkegaard. 2006. Biofumigation and enhanced biodegradation: opportunity and challenge in soilborne pest and disease management. Critical Reviews in Plant Sciences 25: 235-265.

Mazzola, M., J. Brown, A.D. Izzo, and M.F. Cohen. 2007. Mechanism of action and efficacy of seed meal induced pathogen suppression differ in a Brassicaceae species and time dependent manner. Phytopathology 97: 454-460.

Molina, O.I. 2009. Effect of green manures and organic amendments on verticillium wilt of potato in Manitoba. M.Sc. Thesis, University of Manitoba, Winnipeg, MB.

Moore, A.D., N.L. Olsen, A.M. Carey, and A.B.. Leytem. 2011. Residual effects of fresh and composted dairy manure application on potato production. American Potato Journal of Research 88: 324-332.

Morra, M.J., and J.A. Kirkegaard. 2002. Isothiocyanate release from soilincorporated Brassica tissues. Soil Biology and Biochemistry 34: $1683-1690$.

Neeteson, J.J., and H.J.C. Zwetsloot. 1989. An analysis of the response of sugar-beet and potatoes to fertilizer nitrogen and soil mineral nitrogen. Netherlands Journal of Agricultural Science 37: 129-141.

Njoroge, S.M.C., M.B. Riley, and A.P. Keinath. 2008. Effect of incorporation of Brassica spp. residues on population densities of soilborne microorganisms and on damping-off and Fusarium wilt of watermelon. Plant Disease 92: 287-294.

Ochiai, N., M.L. Powelson, F.J. Crowe, and R.P. Dick. 2008. Green manure effects on soil quality in relation to suppression of Verticillium wilt of potatoes. Biology and Fertility of Soils 44: 1013-1023. 
Olivier, C., S.F. Vaughn, E.S.G. Mizubuti, and R. Loria. 1999. Variation in allyl isothiocyanate production within Brassica species and correlation with fungicidal activity. Journal of Chemical Ecology 25: 2687-2701.

Pegg, G.F., and B.L. Brady. 2002. Verticillium wilts. New York: CAB International.

Powelson, M.L., and R.C. Rowe. 1993. Biology and management of early dying of potatoes. Annual Review of Phytopathology 31: 111-126.

Rowe, R.C., and M.L. Powelson. 2002. Potato early dying: management challenges in a changing production environment. Plant Disease 86: 1184-1193.

Rowe, R.C., J.R. Davis, M.L. Powelson, and D.I. Rouse. 1987. Potato early dying: causal agents and management strategies. Plant Disease 71: 482-489.

Schnathorst, W.C. 1981. Life cycle and epidemiology of Verticillium. In Fungal wilt diseases of plants, ed. M.E. Mace, A.A. Bell, and C.H. Beckman, 81-111. NY: Academic Press.

Sincik, M., Z.M. Turan, and A.T. Goksoy. 2008. Responses of potato (Solanum tuberosum L.) to green manure cover crops and nitrogen fertilization rates. American Journal of Potato Research 85: 150158.

Smolinska, U., M.J. Morra, G.R. Knudsen, and R.L. James. 2003. Isothiocyanates produced by Brassicaceae species as inhibitors of Fusarium oxysporum. Plant Disease 87: 407-412.

Sorensen, L.H., A.T. Scheneider, and J.R. Davis. 1991. Influence of sodium polygalacturonate sources and improved recovery of Verticillium species from soil. (Abstr.). Phytopathology 81: 1347.

Stark, J.C., and G.A. Porter. 2005. Potato nutrient management in sustainable cropping systems. American Journal of Potato Research 82: 329-338.

Tenuta, M., and G. Lazarovits. 2002a. Ammonia and nitrous acid from nitrogenous amendments kill the microsclerotia of Verticillium dahliae. Phytopathology 92: 255-264.

Tenuta, M., and G. Lazarovits. 2002b. Identification of specific soil properties that affect the accumulation and toxicity of ammonia to Verticillium dahliae. Canadian Journal Plant Pathology 24: 219-229.

Tenuta, M., and G. Lazarovits. 2004. Soil properties associated with the variable effectiveness of meat and bone meal to kill microsclerotia of Verticillium dahliae. Applied Soil Ecology 25: 219-236.
Tenuta, M., K.L. Conn, and G. Lazarovits. 2002. Volatile fatty acids in liquid swine manure can kill microsclerotia of Verticillium dahliae. Phytopathology 92: 548-552.

Termorshuizen, A.J., E. van Rijn, D.J. van der Gaag, C. Alabouvette, Y. Chen, J. Lagerlöf, A.A. Malandrakis, E.J. Paplomatas, B. Rämert, J. Ryckeboer, C. Steinberg, and S. Zmora-Nahum. 2006. Suppressiveness of 18 composts against 7 pathosystems: Variability in pathogen response. Soil Biology and Biochemistry 38: 2461-2477.

Tsror, L., E. Shlevin, and I. Peretz-Alon. 2005. Efficacy of metam sodium for controlling Verticillium dahliae prior to potato production in sandy soils. American Journal of Potato Research 82: 419-423.

Uppal, A.K., A. El Hadrami, L.R. Adam, M. Tenuta, and F. Daayf. 2007. Pathogenic variability of Verticillium dahliae isolates from potato fields in Manitoba and screening of bacteria for their biocontrol. Canadian Journal of Plant Pathology 29: 141-152.

Uppal, A.K., A. El Hadrami, L.R. Adam, M. Tenuta, and F. Daayf. 2008. Biological control of potato Verticillium wilt under controlled and field conditions using selected bacterial antagonists and plant extracts. Biological Control 44: 90-100.

Weichart, D., and S. Kjelleberg. 1996. Stress resistance and recovery potential of culturable and viable but nonculturable cells of Vibrio vulnificus. Microbiology 142: 845-853.

Weil, R.R., and F. Magdoff. 2004. Significance of soil organic matter to soil quality and health. In Soil organic matter in sustainable agriculture, ed. F. Magdoff and R.R. Weil, 1-43. Boca Raton, FL: CRC Press.

Wiggins, B.E., and L.L. Kinkel. 2005a. Green manure and crop sequences influence alfalfa root rot and pathogen inhibitory activity among soil-borne streptomycetes. Plant and Soil 268: 271-283.

Wiggins, B.E., and L.L. Kinkel. 2005b. Green manure and crop sequences influence potato diseases and pathogen inhibitory activity of indigenous Streptomycetes. Phytopathology 95: 178-185.

Zheng, W., S.R. Yates, S.K. Papiernik, and J. Nunez. 2006. Conversion of metam sodium and emission of fumigant from soil columns. Atmospheric Environment 40: 7046-7056.

Zinati, G.M., Y.C. Li, and H.H. Bryan. 2001. Utilization of compost increases organic carbon and its humin, humic and fulvic acid fractions in calcareous soil. Compost Science and Utilization 9: $156-162$. 